\title{
Sosyal Bilgiler Öğretmenlerinin Sınıf Yönetimi Yeterliliklerine İlişkin Okul Yöneticilerinin Görüşlerinin Değerlendirilmesi*
}

\section{Evaluating the Views of the School Principals, Concerning the Proficiency Level of Social Studies Teachers in Classroom Management}

İsmail Sari ${ }^{\text {a,** }}$

${ }^{a}$ Necmettin Erbakan Üniversitesi, Eğitim Bilimleri Fakültesi, Sosyal Bilgiler Eğitimi Bölümü, 42090, Konya/Türkiye. ORCID: 0000-0002-8592-7758

\section{MAKALE BİLGISİ}

\section{Makale Geçmişi:}

Başvuru tarihi: 21 Eylül 2017

Düzeltme tarihi: 01 Aralık 2017

Kabul tarihi: 17 Aralık 2017

\section{Anahtar Kelimeler:}

Sosyal Bilgiler Öğretmeni

Sınıf Yönetimi

Yeterlilik

\section{ARTICLE INFO}

\section{Article history:}

Received 21 September 2017

Received in revised form 01 December 2017

Accepted 17 December 2017

\section{Keywords:}

Social Studies Teacher

Classroom Management

Proficiency
ÖZ

$\mathrm{Bu}$ araştırmanın amacı, sosyal bilgiler öğretmenlerinin sınıf yönetimi yeterliliklerini okul yöneticilerinin görüşleri doğrultusunda incelemektir. Araştırma, genel tarama modelinde betimsel bir çalışmadır. Araştırmaya ilişkin veriler, 2012-2013 eğitim-öğretim y1lı bahar döneminde Diyarbakır'ın Ergani İlçesindeki devlet ortaokullarında görev yapan okul yöneticileri üzerinden elde edilmiştir. Veriler, "Sınıf Yönetimi Becerisini Değerlendirme Ölçeği" aracılı̆̆ıyla toplanmıştır. Araştırma sonucunda, sosyal bilgiler öğretmenlerinin sınıf yönetimi yeterlilik düzeyleri okul yöneticileri tarafindan "yeterli” seviyesinde gözlemlenmiştir. Okul yöneticilerinin görüşlerine göre, sosyal bilgiler öğretmenlerinin "etkinlik yönetimine" ilişkin yeterlilik düzeylerinin düşük düzeyde olduğu saptanmıştır. Ayrıca, yaş ve kıdem değişkenlerine göre, sosyal bilgiler öğretmenlerinin sınıf yönetimi yeterliliklerine ilişkin okul yöneticilerinin görüşlerinin anlamlı bir farklılık göstermediği gözlemlenmiştir. Dolayısıyla, sosyal bilgiler öğretmenlerinin sınıf yönetiminin "etkinlik yönetimi” boyutunda, kendilerini geliştirmelerine olanak sağlayacak çalışmalar yapılması önerilmektedir.

\section{A B S T R A C T}

The purpose of this study is to examine the classroom management competences of social studies teachers according to the opinions of school principals. The research is a descriptive study in the general survey model. The data related to the research were gathered from the school principals who work in state secondary schools in the Ergani District of Diyarbakır during the spring semester of 2012-2013 academic year. The data were gathered by the "Classroom Management Assessment Scale". As a result of the research, the classroom management proficiency levels of social studies teachers were observed by the school principals at the level of "sufficient". According to the opinions of the school principals, it was determined that the level of proficiency of social studies teachers regarding "activity management" was low. Additionally it was observed that the opinions of the school principals related to the classroom management competences of the social studies teachers did not show any significant difference according to the age and seniority variables. Therefore, it is recommended that social studies teachers should carry out studies that will enable them to improve themselves in the dimension of activity management of classroom management.

\section{Giriş}

Çağdaş hayatın yeni şartları ve yaşanmakta olan değişim süreci sosyal, ekonomik ve kültürel alanda önemli ilerlemelerin kaydedilmesini sağlamıştır (Yalçınkaya, 2003:
1). $\mathrm{Bu}$ gelişmeler, bir toplumun gelişim ve değişimininde anahtar rolünü üstlenen (Farooq, 2011: 23) eğitim kurumlarından beklentileri artırmış olmakla birlikte aynı zamanda eğitim kurumlarını zorunlu olarak değişmeye mecbur etmiştir. $\mathrm{Bu}$ sürecin bir sonucu olarak; eğitim

\footnotetext{
* Bu çalışma, 2013 yılında Hasan Kalyoncu Üniversitesi Sosyal Bilimler Enstitüsü tarafından kabul edilen "Sosyal Bilgiler Öğretmenlerinin Sinıf Yönetimi Yeterliliklerine İlişkin Okul Yöneticilerinin Görüşlerinin Değerlendirilmesi (Diyarbakır İli Ergani İlçesi Örneği)” adlı Yüksek Lisans tezinden türetilmiştir.

** Sorumlu yazar/Corresponding author.

e-posta: ism984@hotmail.com
} 
kurumları eğitime ilişkin yapılan araştırmaları ve bu alanda yaşanan gelişmeleri de dikkate alarak bu çerçevede bakış açılarını değiştirmeli ve yeni bir vizyon geliştirebilmelidir (Yalçınkaya, 2003: 1). Aksi takdirde eğitim kurumları toplumun ihtiyaçlarını karşılama noktasında geri kalacaktır. Bununla birlikte çağdaş hayatın sorunlarını çözmekten uzak, bu günün ihtiyaçlarına cevap veremeyen işlevsiz birer hantal kurum haline gelecektir.

Eğitim yönetimi, eğitim organizasyonlarının çalışma ve uygulama alanıdır. Eğitim yönetiminin gayesi, öğrenmeöğretme faaliyetleri konusunda başarı ve verimliliği artırmaya yönelik kaliteli çalışmalar yürütmektir (Sharma, 2009: 1). Eğitim yönetiminin kalitesi, öğrenme-öğretme etkinliklerine hizmet edebilecek kaynakların kullanımıyla doğrudan ilgilidir. Mevcut kaynakların öğrenmeyi kolaylaştıracak şekilde bireysel farklılıkları da dikkate alarak eğitsel hedefler doğrultusunda kullanımı, eğitim yönetiminin kalitesini artıracaktır (Başar, 2005: 5). Eğitim yönetimi; eğitim örgütlerinin belirlemiş olduğu hedefleri gerçekleştirmek üzere insan ve madde kaynaklarının eğitimöğretim faaliyetleriyle ilgili bütün basamaklarda en etkili şekilde kullanılması durumudur (Demir, 2006: 1-2). Dolayısıyla eğitim yönetimi alanında hedeflenen başarı, önemli oranda, sınıf yönetimi alanında sergilenen performansa bağlıdır (Başar, 2005: 6). Sınıf yönetimi ile ilgili birbirinden farklı tanımlar mevcuttur. Bunlardan bazıları şu şekilde ifade edilmiştir: Sınıf yönetimi; sınıfta etkili bir öğrenme-öğretme ortamı sağlamak üzere öğrenci, zaman, içerik, program, teknoloji gibi bütün temel unsurların birbirleriyle eşgüdümlerinin sağlanması ve uygulanması durumudur (Sarıtaş, 2006: 53). Öğretmen tarafından sınıf ortamında pozitif sosyal etkileşimin oluşturulması ve öğrencilerin öğrenme faaliyetlerine etkin bir şekilde katılımlarının sağlanması sürecidir (Burden, 2003: 2). Eğitimin belirlemiş olduğu hedefler doğrultusunda, öğrenci davranışlarında amaçlı davranış değişikliği sağlamak ve öğrenme faaliyetlerini gerçekleştirmek üzere sınıf içi etkinliklerine yol gösterme sürecidir (Arslan, 2008: 18). Eğitim-öğretim etkinliklerinin etkili bir şekilde gerçekleştirilebilmesi için gerekli öğrenme-öğretme ortamının kurallar dahilinde oluşturulması ve sürdürülmesi sürecidir (Jonhson vd., 1997: 66). Sınıf yönetimiyle ilgili tanımlar birbirinden farklı olsa da çoğu araştırmacının vurguladığ 1 ortak nokta, eğitim hedeflerinin en etkin bir şekilde nasıl gerçekleştirilmesi gerektiği yönündedir. $\mathrm{Bu}$ çerçevede, sınıf içi öğrenme-öğretme faaliyetlerini verimli bir şekilde sürdürme, eğitimde başarıyı yakalama ve bu başarıların devamını sağlama önemli oranda sınıf yönetimini oluşturan boyutlarda sergilenen performansa dayanmaktadır.

Sınıf, öğrenme-öğretme faaliyetleri boyunca programsal öğelerin uygulanmasına yönelik çalışmaların yapıldı ̆̆ı ve belirlenen hedeflerin gerçekleşme düzeyinin hangi miktarda olduğunun saptanmaya çalışıldığı bir yapıdır. $\mathrm{Bu}$ yapının temel öğesini oluşturan ve bireysel farklılıkları göz önünde bulundurulması gereken öğrenci öğesi, öğrenimi boyunca birçok değişken tarafından etkilenir. Bu yönüyle sınıf, eğitim-öğretim faaliyetlerinin hedefleri doğrultusunda bireysel farklılıkların da dikkate alındığı; bilgi, beceri, tutum ve değerlerin kazandırılmaya çalışıldığı özel bir alan olarak düşünülebilir (Aydın, 2012: 1). Bu doğrultuda eğitimöğretim faaliyetlerinin verimli bir şekilde gerçekleştirilmesinde ve devamının sağlanmasında sınıf yönetiminin sahip olduğu önem ön plana çıkmaktadır. Eğitim yönetiminde birçok unsur etkili olmasına rağmen, temel basamağını sınıf yönetimi oluşturur. Eğitim-öğretim faaliyetlerini gerçekleştirmek üzere gerekli olan bütün kaynaklar yani; öğrenci, öğrenme-öğretme materyalleri, program ve diğer öğeler sınıfın içinde yer alır (Çalık, 2009: 6). Öğretmenin sınıf yönetimi alanındaki yeterliliği ve öğrenme-öğretme faaliyetlerini gerçekleştirmeye yönelik mevcut kaynakları etkin bir şekilde kullanmaya yönelik becerisi öğrencilerin öğrenme başarılarını ve gelişimlerini olumlu etkileyecektir.

Öğretmenin sahip olduğu misyon ve öğrenme-öğretme sürecinde kendisine yönelik beklentiler, kendisini sınıf içi değişkenlerinin en önemli öğesi haline getirmiştir. Sınıfın öğrenme-öğretme faaliyetleri için hazır hale getirilmesi, sınıf kurallarının öğrencilerle belirlenip mevcut kuralların öğrenciler tarafindan içselleştirilmesine yönelik çalışmaların yapılması, öğretim faaliyetlerinin belirlenmiş hedefler doğrultusunda düzenlenmesine ve sürdürülmesine yönelik uygulamaların yapılması, öğrencilerin sınıf içi etkinlikler sürecine dâhil edilmesi ve bu sürecin gerektirmiş olduğu kurallara en uygun şekilde uyulmasının sağlanması; sınıf yöneticisi olarak öğretmene yönelik temel beklentilerdendir (Ağaoğlu, 2003: 9). Öğretmenlerin etkili bir öğrenmeöğretme faaliyeti gerçekleştirebilmeleri için kendilerinden sahip olmaları istenilen en önemli beceriler şu şekilde sıralanabilir: Sınıf içerisinde bulunan öğrenci ve madde unsurlarını eğitimin hedefleri kapsamında harekete geçirme, öğrenme-öğretme süresi boyunca öğrencileri yönlendirme ve yönetme becerisidir. Bundan dolayı sınıf yönetimi; öğrenme-öğretme faaliyetlerinin gerçekleştirilmesinde ve eğitimin hedefleri doğrultusunda yönlendirilmesinde önemli bir unsurdur, denilebilir (Demirtaş, 2005: 4).

Eğitimde yeterlilik; öğrencilerin eğitimin hedefleri doğrultusunda istenilen seviyeye ulaştırılmaları için öğretmenlerin genel kültür, alan bilgisi ve pedagojik formasyon alanlarında sahip olmaları gereken bütün özelliklerdir. Öğretmenin sınıf yönetimi boyutlarındaki yeterlilikleri hem verimli bir öğrenme-öğretme ortamının gerçekleştirilmesinde hem de olumlu bir sınıf ikliminin oluşturulmasında önem arz etmektedir (Kuran, 2002: 253). Öğretmenlerin sınıf yönetimi alanında kendilerine ilişkin yeterlilik duygusu ve öğrenme-öğretme faaliyetleri boyunca bunu sergileyebilme becerisi öğrenme-öğretme sürecini birçok boyutuyla olumlu etkilemektedir. Yeterlik duygusu etkili bir sınıf kültürünün oluşturulmasında, öğrenmeöğretme aktivitelerinin verimli bir şekilde sürdürülmesinde ve öğrenci-öğretmen ilişkisinin olumlu tutum ve davranışlar çerçevesinde şekillendirilmesinde etkili bir rol oynamaktadır. Yeterlilik duygusu yüksek olan öğretmenlerin ders işlediği sınıflarda öğrencilerin kendilerine ilişkin güveni artar, öğrencilerin öğrenmeye ilişkin kişisel ihtiyaçları karşılanır ve öğrencilerin öğrenme aktivitelerine katılım oranı artış gösterir (İpek, 2003: 91-93). Belirtilen olanakların sağlanması durumunda, öğretmen derse ilişkin sahip olduğu zamanını sınıf içi denetimi sağlamaya yönelik değil; sınıf içi öğrenme-öğretme aktivitelerini daha verimli bir şekilde sürdürmeye yönelik kullanabilecektir.

Sınıf yönetimi, kritik bir yetenek arenasıdır. Öğretmenlerin bu alanda başarılı olunması isteniyorsa bu alanla ilgili olarak kendilerine hem kaliteli bir eğitim verilmeli hem de kendileri yaptıkları çalışmalardan dolayı her zaman desteklenmelidir. 
Öğretmenlerin göreve başlama öncesinde uygulamalı olarak aldıkları eğitim ise onların sınıf yönetimi yeterliliklerini daha da artıracaktır (Simonsen vd., 2008: 351). Etkili bir öğrenme-öğretme ortamının sağlanmasında birçok sınıf içi değişken bulunmaktadır. Öğretmenin sınıf yönetimi yeterliliği bu değişkenler arasında önemli bir yere sahiptir. Öğrenmeye elverişli bir sınıf ikliminin oluşturulmasında, sınıf içinde yer alan materyallerin öğrenme faaliyetlerine hizmet edecek şekilde düzenlenmesinde, öğrenci-öğrenci ve öğretmen-öğrenci arasındaki ilişkilerin etkili bir şekilde sürdürülmesinde, zamanın verimli bir şekilde kullanılmasında, öğretme süresi boyunca disiplinin sağlanmasında, öğretim faaliyetlerinin kontrollü bir şekilde sürdürülmesinde (Koçak ve Akın, 2007: 355), sınıf içi davranış problemlerinin engellenmesine yönelik alınan ortak kararların uygulanmasında, öğrenciler tarafından demokratik değerlerin benimsenmesinde ve öğrencilerin derse yönelik motivasyonlarının artırılmasında öğretmenin sınıf yönetimine ilişkin yeterliliği önemli bir rol oynamaktadır.

Eğitim bilimleri alanında kat edilen gelişmeler ve öğrenmeöğretme faaliyetlerine etki eden sınıf içi değişkenleriyle ilgili yapılan araştırmalar sınıf yönetiminin sahip olduğu önemi gözler önüne sermiştir. Öğrencilerin akademik başarılarının artırılmasında, sınıf içinde olumlu bir iletişimin gerçekleştirilmesinde, zamanın verimli şekilde kullanılmasında, istendik davranışların kazandırılmasında vb. oynadığı önemli rol dolayısıyla; öğretmenlerin sınıf yönetimine ilişkin yeterliliklerinin ne kadar gerekli olduğu düşüncesi daha iyi anlaşılmaya başlanmıştır (Arslan, 2008: 3). Dolayısıyla, kaliteli bir öğretme-öğrenme faaliyetinin gerçekleştirilmesinde öğretmenin sahip olması gereken niteliklerin yanı sıra sınıf yönetimi alanındaki yeterliliği; sınıf içindeki faaliyetlerin daha verimli bir şekilde gerçekleştirilmesine olanak sağlar. Öğretmenlerin sınıf yönetimi alanındaki yeterliliklerinin artırılması hem bu alandaki başarıların artmasına hem de başarılı bireylerin yetiştirilmesine olanak sağlar. Darling Hammond'e (2006: 4) göre, öğretmenlerin öğretme ve öğrenmeye ilişkin hazırlık bilgisi ve düzeyi, konu alan bilgisi, deneyimi gibi birçok faktör öğretmen yeterliliğinde önemli rol oynamaktadır. Kuşkusuz, bu öğeleri taşıyan ve bu öğelerin gerektirdiklerini yerine getiren öğretmenler eğitim dünyasında önemli atılımlara öncülük edecektir.

Sınıf yönetimine ilişkin alanyazındaki araştırmalar incelendiğinde; öğretmenlerin sınıf yönetimi yeterliliklerini belirlemeye yönelik çok sayıda araştırmaya rastlanılmışsa da hem sosyal bilgiler öğretmenlerinin sınıf yönetimi yeterliliklerini hem de okul yöneticilerinin bakış açıları doğrultusunda öğretmenlerin sınıf yönetimi yeterliliklerini belirlemeye yönelik herhangi bir çalışmaya rastlanılmamıştır. Dolayısıyla bu araştırma, sosyal bilgiler öğretmenlerinin:

(i) Sınıf yönetimi yeterliliklerinin okul yöneticileri görüşleri doğrultusunda belirlenmesine olanak sağlaması,

(ii) Sınıf yönetimi alt boyutlarıyla ilgili zayıf ve güçlü taraflarını ortaya koyması,

(iii) Elde edilen bulgular doğrultusunda niteliklerini artırmaya yönelik öneriler sunması, (iv) Sınıf yönetimi ile ilgili alanyazındaki boşluğu doldurmaya katkı sağlaması açısından önemli olduğu düşünülmektedir.

Bu araştırmanın amacı, Diyarbakır-Ergani İlçe Milli Eğitim Müdürlüğü'ne bağlı ortaokullarda çalışmakta olan sosyal bilgiler öğretmenlerinin sınıf yönetimi yeterliliklerini, okul yöneticilerinin görüşleri doğrultusunda belirlemeye çalışmaktır. Bu araştırmanın amacına ulaşmak için aşağıdaki sorulara yanıt aranmıştır:

(i) Okul yöneticilerinin, sosyal bilgiler öğretmenlerinin sınıf yönetimi yeterliliklerine ilişkin görüşleri nasildir?

(ii) Okul yöneticilerinin, yaş değişkenine göre sosyal bilgiler öğretmenlerinin sınıf yönetimi yeterliliklerine ilişkin görüşleri farklılık göstermekte midir?

(iii) Okul yöneticilerinin, mesleki kıdem değişkenine göre sosyal bilgiler öğretmenlerinin sınıf yönetimi yeterliliklerine ilişkin görüşleri farklılık göstermekte midir?

(iv) Okul yöneticilerinin, sosyal bilgiler öğretmenlerinin sınıf yönetimi yeterliliklerine ilişkin sınıf yönetiminin boyutlarındaki değerlendirmeleri nasıldır?

\section{Yöntem}

\subsection{Araştırmanın Yöntemi}

Araştırmada konu alanına ilişkin mevcut durum olduğu haliyle betimlenmeye çalışıldığ 1 için tarama modeli kullanılmıştır. Tarama modelleri, araştırmaya konu olan herhangi bir nesne, olay veya bireyin kendi şartları içerisinde kendisine herhangi bir müdahalede bulunulmaksızın; mevcut durumu var olan şekliyle betimlemeye çalışan, araştırma yaklaşımlarıdır. Tarama modellerinde, geçmişte ya da halen varlığını devam ettiren duruma yönelik değiştirme ve etkileme gayreti gösterilmez. Sadece araştırmaya konu olan birey, nesne ya da olay en uygun şekilde gözlemlenip betimlenmeye çalışılır (Karasar, 2012).

\subsection{Araştırmanın Evreni ve Sınırlılıkları}

Çalışma, 2012-2013 eğitim-öğretim yılı Diyarbakır ili Ergani İlçe Milli Eğitim Müdürlüğü'ne bağlı 28 devlet ortaokulunda görev yapan 69 okul yöneticisini kapsamaktadır. Böylece araştırmanın evreni, 69 ortaokul okul yöneticisinden oluşmaktadır. Çalışma, kendini örnekleyen evren üzerinden yapılmış, ayrıca örneklem alma yoluna gidilmemiştir. Uygulanan ölçeklerin 17'si, ölçek yönergesinde belirtilen kurallara uygun olarak doldurulmadığı için geçersiz sayılmış; ancak geriye kalan ölçeklerin 52'si geçerli sayılmıştır.

Tablo 1'deki veriler, çalışmaya katılan (31-40) yaş aralığındaki okul yöneticilerinin \% 55,7 ile en fazla; (41-50) yaş aralığındaki okul yöneticilerinin \% 11,5 ile en az yaş grubunu oluşturduğunu göstermektedir. Bununla birlikte mesleki kıdeme ilişkin Tablo 1'deki veriler incelendiğinde, çalışmaya katılan (1-5) yıl arası mesleki kıdeme sahip okul yöneticileri \% 50 ile en fazla; (16-20 y1l arası) mesleki kıdeme sahip okul yöneticileri \% 5,7 ile en az mesleki kıdem grubunu oluşturmaktadır. 
Tablo 1. Araştırma Grubunu Oluşturan Okul Yöneticilerinin Kişisel Özelliklerine İlişkin Bilgiler

\begin{tabular}{ccc}
\hline \multicolumn{3}{l}{ Okul Yöneticilerinin Yaşa Göre Dağılımı } \\
\hline Yaş & $\mathrm{N}$ & $\%$ \\
\hline $20-24$ & - & - \\
$25-30$ & 9 & 17.3 \\
$31-40$ & 29 & 55.7 \\
$41-50$ & 6 & 11.5 \\
51 ve üzeri & 8 & 15.3 \\
Toplam & 52 & 100 \\
\hline Okul Yöneticilerinin Mesleki K1deme Göre Dağ1lımı \\
\hline Mesleki K1dem & \multicolumn{2}{c}{} \\
\hline 1-5 y1l aras1 & 26 & 50 \\
6-10 y1l arası & 11 & 21.1 \\
11-15 y1l aras1 & 6 & 11.5 \\
16-20 y1l aras1 & 3 & 5.7 \\
21 y1l ve üzeri & 6 & 11.5 \\
Toplam & 52 & 100 \\
\hline
\end{tabular}

Araştırmaya ilişkin sınırlılıklar aşağıda belirtilmiştir.

(i) $\mathrm{Bu}$ araştırmadan elde edilen veriler, 2012-2013 eğitim-öğretim yılında Diyarbakır-Ergani İlçe Milli Eğitim Müdürlüğü'ne bağlı ortaokullarda görev yapan okul yöneticilerinin görüşleri ile sınırlıdır.

(ii) Araştırmada elde edilen bulgular, "Sınıf Yönetimi Becerisini Değerlendirme Ölçeği” ile toplanan verilerle sinırlıdır.

(iii) $\mathrm{Bu}$ çalışma, araştırmaya katılan okul yöneticilerinin yaşı ve mesleki kıdemleri ile sınırlıdır.

\subsection{Araştırmada Kullanılan Ölçme Aracı}

$\mathrm{Bu}$ çalışmadaki veriler, Baloğlu (1998) tarafından geliştirilen; Ağaoğlu (2004) tarafindan ise uyarlaması yapılan "Sınıf Yönetimi Becerisini Değerlendirme Ölçeği" ile toplanmıştır.

Ölçekteki maddeler; 4'lü likert tipi ölçek üzerinden "kesinlikle katılıyorum" 4, "katılıyorum" 3, "katılmıyorum" 2, "kesinlikle katılmıyorum" 1 olarak değerlendirilmiştir. Okul yöneticilerine uygulanan veri toplama aracının iç güvenirlik kat sayısı $\alpha=0.92$ olarak hesaplanmıştır. Cronbach Alfa değerine göre ölçeğin güvenirliği yeterli olarak kabul edilebilir.

Aritmetik ortalamalara ilişkin veriler yorumlanırken, 1.001.75 arasında yer alan ortalama puan değerleri "kesinlikle katılmiyorum", 1.76-2.50 arasında yer alan ortalama puan değerleri "katılmiyorum", 2.51-3.25 arasında yer alan ortalama puan değerleri "katılıyorum" ve 3.26-4.00 arasındaki ortalama puan değerlerinin ise "kesinlikle katılıyorum" olarak değer taşıdığı kabul edilmiştir. Verilerin yorumlanmasında önemli bir rol oynayan düzeylerin yer aldığı bu sayısal aralıklar, seçeneklere verilen en düşük değer olan 1 ile seçeneklere verilen en yüksek değer olan 4 arasındaki seri genişliğinin düzey sayısına bölünmesi ile elde edilmiştir (Oral, 2000: 31).

Mayıs 2013'te ölçek yöneticilere dağıtılmış, ölçek uygulaması sırasında yöneticilerle ilişki kurulmuş, ölçeğe ilişkin gerekli açıklamalar yapıldıktan sonra ölçeğin uygulanması sağlanmıştır. Okul yöneticileri, bir haftada 3 ders saati boyunca sosyal bilgiler öğretmenlerini gözlemledikten sonra ölçekte yer alan ifadeler çerçevesinde görüşlerini belirtmişlerdir. Ayrıca uygulama öncesinde, sosyal bilgiler öğretmenleri yapılacak çalışma konusunda araştırmacı tarafından haberdar edilmiştir.

\subsection{Verilerin Analizi}

Araştırmanın genel amacı ve alt problemlerine ilişkin toplanan veriler kodlanıp bilgisayara aktarıldıktan sonra verilerin istatistiksel çözümlemeleri için SPSS 19.0 paket programı kullanılmıştır.

Araştırmada verilerin çözümlenmesi aşamasında, araştırma amaçları doğrultusunda, yüzde, aritmetik ortalama, standart sapma, ikiden çok küme karşılaştırmalarında ise tek yönlü varyans analizi (ANOVA) istatistik tekniklerinden yararlanılmıştır. Yapılan istatistiksel çözümlemelerde anlamlılık düzeyi 0.05 olarak alınmıştır.

\section{Bulgular ve Yorumlar}

Bu bölümde, araştırma probleminin çözümlenmesi amacıyla sosyal bilgiler öğretmenlerinin sınıf yönetimi yeterliliklerine ilişkin okul yöneticilerinin görüşleriyle ilgili toplanan verilerin istatistiksel çözümlemelerine, alt problemlerle ilgili elde edilen bulgulara ve yorumlara yer verilmiştir.

3.1. Okul Yöneticilerinin, Sosyal Bilgiler Öğretmenlerinin Sınıf Yönetimi Yeterliliklerine İlişkin Görüşleri Nasıldır?

Çalışmanın bu alt problemine cevap olabilecek betimsel istatistikler Tablo 2'de verilmiştir.

Tablo 2. Sosyal Bilgiler Öğretmenlerinin Sınıf Yönetimi Yeterliliklerine İlişkin Okul Yöneticilerinin Görüşlerini Betimleyen İstatistik Değerler

\begin{tabular}{cccc}
\hline & $\mathrm{N}$ & $\overline{\mathrm{X}}$ & $\mathrm{Ss}$ \\
\hline Çalışmanın İstatistik Değerleri & 52 & 3.25 & 0.397 \\
\hline
\end{tabular}

Tablo 2'de görüldüğü gibi sosyal bilgiler öğretmenlerinin sınıf yönetimi yeterliliklerine ilişkin okul yöneticilerinin görüşlerinin değerlendirilmesinde aritmetik ortalama 3.25 standart sapma ise 0.397 olarak hesaplanmıştır. Araştırma sonucuna göre; sosyal bilgiler öğretmenlerinin sınıf yönetimine ilişkin yeterlilik düzeyleri okul yöneticileri tarafından "katılıyorum" düzeyinde gözlemlenmiştir.

\subsection{Okul Yöneticilerinin, Yaş Değiş̧kenine Göre} Sosyal Bilgiler Öğretmenlerinin Sinıf Yönetimi Yeterliliklerine İlişkin Görüşleri Farklılık Göstermekte Midir?

Çalışmanın bu alt problemine cevap olabilecek betimsel istatistikler Tablo 3 ve Tablo 4 'te verilmiştir.

Tablo 3. Yaş Değişkenine Göre Sosyal Bilgiler Öğretmenlerinin Sınıf Yönetimi Yeterliliklerine İlişkin Okul Yöneticilerinin Görüşlerinin Puan Değerleri

\begin{tabular}{lccc}
\hline Yaş & N & $\bar{X}$ & Ss \\
\hline $20-24$ & - & - & - \\
$25-30$ & 9 & 216.77 & 29.05 \\
$31-40$ & 29 & 205.00 & 23.94 \\
$41-50$ & 6 & 196.50 & 29.88 \\
51 ve üzeri & 8 & 219.87 & 20.08 \\
Toplam & 52 & 208.34 & 25.42 \\
\hline
\end{tabular}


Tablo 3'te 25-30 yaş aralığındaki okul yöneticilerinin $(\bar{X}=216.77) ; 31-40$ yaş aralığındaki okul yöneticilerinin $(\bar{X}=205.00) ; \quad 41-50$ yaş aralığındaki okul yöneticilerinin $(\bar{X}=196.50) ; 51$ ve üzeri yaş aralığındaki okul yöneticilerinin ise $(\bar{X}=219.87)$ puan değerine sahip oldukları görülmektedir. Yaş grupları arasında değerlendirmeye ilişkin düzenli bir puan akışı bulunmamakla birlikte 51 ve üzeri yaş grubunu temsil eden okul yöneticilerinin, sosyal bilgiler öğretmenlerinin sınıf yönetimi yeterliliklerine ilişkin görüşleri diğer yaş gruplarındaki okul yöneticilerine göre daha olumlu olduğu söylenebilir.

Tablo 4. Yaş Değişkenine Göre Sosyal Bilgiler Öğretmenlerinin Sınıf Yönetimi Yeterliliklerine İlişkin Okul Yöneticilerinin Görüşlerinin ANOVA Testi Sonuçları

\begin{tabular}{lccccc}
\hline Varyans Kaynağ 1 & Kareler Top. & Kareler Ort. & $\mathrm{F}$ & $\mathrm{p}$ & Fark \\
\hline Gruplar Aras1 & 2869.839 & 956.613 & & & \\
Grup İçi & 30091.931 & 626.915 & 1.52 & 0.22 & - \\
Toplam & 32961.769 & & & & \\
\hline$(p>0.05)$ & & & & &
\end{tabular}

Tablo 4 incelendiğinde, sosyal bilgiler öğretmenlerinin sınıf yönetimi yeterliliklerine ilişkin okul yöneticilerinin görüşlerinin değerlendirilmesinde yaş değişkenine göre 0.05 anlamlılık düzeyinde varyans analizi testinden elde edilen $p$ : 0.22 değeri, anlamlılık düzeyinden yüksek olduğu için ( $p>0.05)$ farkın anlamlı olmadığı görülmektedir. Yaş değişkeninin okul yöneticilerinin görüşleri üzerinde etkisinin olmadığı sonucuna ulaşılmıştır.

3.3. Okul Yöneticilerinin, Mesleki Kıdem Değişkenine Göre Sosyal Bilgiler Öğretmenlerinin Sınıf Yönetimi Yeterliliklerine İlişsin Görüşleri Farklılık Göstermekte Midir?

Çalışmanın bu alt problemine cevap olabilecek betimsel istatistikler Tablo 5 ve Tablo 6'da verilmiştir.

Tablo 5. Mesleki Kıdem Değişkenine Göre Sosyal Bilgiler Öğretmenlerinin Sınıf Yönetimi Yeterliliklerine İlişkin Okul Yöneticilerinin Görüşlerinin Puan Değerleri

\begin{tabular}{lccc}
\hline K1dem & $\mathrm{N}$ & $\overline{\mathrm{x}}$ & $\mathrm{Ss}$ \\
\hline $1-5$ y1l & 26 & 211.53 & 26.33 \\
$6-10$ y1l & 11 & 201.27 & 25.91 \\
$11-15$ y1l & 6 & 204.66 & 18.47 \\
$16-20$ y1l & 3 & 196.66 & 17.50 \\
21 ve üzeri & 6 & 217.00 & 31.07 \\
Toplam & 52 & 208.34 & 25.42 \\
\hline
\end{tabular}

Tablo 5'te, 1-5 y1l mesleki k1deme sahip okul yöneticilerinin $(\bar{X}=211.53) ; \quad 6-10$ yil mesleki kideme sahip okul yöneticilerinin ( $\overline{\mathrm{X}}=201.27)$; 11-15 yıl mesleki kıdeme sahip okul yöneticilerinin $(\bar{X}=204.66)$; 16-20 y1l mesleki kıdeme sahip okul yöneticilerinin ( $\overline{\mathrm{X}}=196.66) ; 21$ y1l ve üstü mesleki k1deme sahip okul yöneticilerinin ise $(\bar{X}=217.00)$ puan değerine sahip oldukları görülmektedir.

Tablo 6 incelendiğinde, sosyal bilgiler öğretmenlerinin sınıf yönetimi yeterliliklerine ilişkin okul yöneticilerinin görüşlerinin değerlendirilmesinde, mesleki kıdem değişkenine göre 0.05 anlamlılık düzeyinde varyans analizi testinden elde edilen $p: 0.62$ değeri, anlamlılık düzeyinden yüksek olduğu için $(p>0.05)$ farkın anlamlı olmadığı görülmektedir. Mesleki kıdem değişkeninin okul yöneticilerinin görüşleri üzerinde etkisinin olmadığı görülmektedir.

Tablo 6. Mesleki Kıdem Değişkenine Göre Sosyal Bilgiler Öğretmenlerinin Sınıf Yönetimi Yeterliliklerine İlişkin Okul Yöneticilerinin Görüșlerinin ANOVA Testi Sonuçları

\begin{tabular}{|c|c|c|c|c|c|}
\hline Varyans Kaynağ 1 & Kareler Top. & Kareler Ort. & $\mathrm{F}$ & $\mathrm{p}$ & Fark \\
\hline Gruplar Arası & 1755.126 & 438.781 & & & \\
\hline Grup İçi & 31206.643 & 663.971 & 0.66 & 0.62 & - \\
\hline Toplam & 32961.769 & & & & \\
\hline
\end{tabular}

$(p>0.05)$

3.4. Okul Yöneticilerinin, Sosyal Bilgiler Öğretmenlerinin Sınıf Yönetimi Yeterliliklerine İlişkin Sınıf Yönetiminin Boyutlarındaki Değerlendirmeleri Nasildir?

Çalışmanın bu alt problemine cevap olabilecek betimsel istatistikler Tablo 7'de verilmiştir.

Tablo 7. Okul Yöneticilerinin, Sınıf Yönetiminin Tüm Boyutlarında Sosyal Bilgiler Öğretmenlerinin Sınıf Yönetimi Yeterliliklerine İlişkin Görüşlerinin Aritmetik Ortalama Puanları

\begin{tabular}{lccc}
\hline \multicolumn{2}{l}{ Sınıf Yönetimi Beceri Ölçeği Boyutları } & $\mathrm{N}$ & $\overline{\mathrm{X}}$ \\
\hline 1-Alan Hakimiyeti & Toplam & 52 & 3.45 \\
\hline 2-Sınıfta İletişim & Toplam & 52 & 3.28 \\
\hline 3-Değerlendirme & Toplam & 52 & 3.28 \\
\hline 4-Sınıf İçi Liderlik & Toplam & 52 & 3.27 \\
\hline 5-Zaman Yönetimi & Toplam & 52 & 3.27 \\
\hline 6-Sınıfta Davranış Yönetimi & Toplam & 52 & 3.26 \\
\hline 7-Amaçlı Davranış Gösterme & Toplam & 52 & 3.23 \\
\hline 8-Planlama & Toplam & 52 & 3.15 \\
\hline 9-Etkinlik Yönetimi & Toplam & 52 & 3.02 \\
\hline
\end{tabular}

Okul yöneticilerinin sosyal bilgiler öğretmenlerinin sınıf yönetimi yeterliliklerine ilişkin alan hâkimiyeti boyutunda $(\overline{\mathrm{X}}=3.45)$; amaçlı davranış gösterme boyutunda $(\overline{\mathrm{X}}=3.23)$; sınıf içi liderlik boyutunda $(\bar{X}=3.27)$; planlama boyutunda $(\bar{X}=3.15) ; \quad$ sınıfta iletişim boyutunda $(\bar{X}=3.28) ;$ sınıfta davranış yönetimi boyutunda $(\overline{\mathrm{X}}=3.26)$; etkinlik yönetimi boyutunda $(\overline{\mathrm{X}}=3.02)$; zaman yönetimi boyutunda $(\overline{\mathrm{X}}=3.27)$; değerlendirme boyutunda $(\bar{X}=3.28)$ puan değerlerine sahip oldukları görülmektedir.

Sosyal bilgiler öğretmenlerinin sınıf yönetimi yeterliliklerine ilişkin okul yöneticilerinin görüşlerine göre, $(\bar{X}=3.45)$ değer ile alan hâkimiyeti en yüksek ortalamayı oluştururken; $(\bar{X}=3.02)$ değer ile etkinlik yönetimi en düşük ortalamayı oluşturmaktadır. Okul yöneticileri, sosyal bilgiler öğretmenlerini sınıf yönetiminin alan hâkimiyeti boyutundaki yeterliliklerini yüksek olarak değerlendirirken; etkinlik yönetimi boyutunda ki yeterliliklerini ise düşük olarak değerlendirmektedir. 


\section{Sonuç ve Değerlendirme}

$\mathrm{Bu}$ çalışmada, sosyal bilgiler öğretmenlerinin sınıf yönetimi yeterliliklerine ilişkin okul yöneticilerinin görüşlerinin yaş ve mesleki kıdem değişkenlerine göre farklılaşıp farklılaşmadığı araştırılmıştır. Araştırma sonucunda aşağıdaki sonuçlara ulaşılmıştır:

(i) Sosyal bilgiler öğretmenlerinin sınıf yönetimi yeterliliklerine ilişkin okul yöneticilerinin görüşleri incelendiğinde, aritmetik ortalamanın $(\bar{X}=3.25)$ olduğu görülmüştür. Araştırma sonucuna göre, sosyal bilgiler öğretmenlerinin sınıf yönetimi yeterlilik düzeyleri okul yöneticileri tarafından "yeterli" seviyesinde gözlemlenmiştir.

Rosas \& West (2009)'da öğretmenlerin ve aday öğretmenlerinin sınıf yönetimine ilişkin algılarını belirlemek üzere bir araştırma yapmıştır. Araştırmada, öğretmenlerin ve öğretmen adaylarının kendilerini sınıf yönetimi alanında yeterli gördükleri sonucuna ulaşılmıştır. Bu sonuç, mevcut araştırma sonucunda elde edilen bulguyla uyum göstermektedir. Özer (2013)'te aday öğretmenlerinin sınıf yönetimi yeterliliklerini belirlemek amacıyla yapmış olduğu araştırmada, aday öğretmenlerinin sınıf yönetimiyle ilgili olarak kendilerini yeterli düzeyde gördükleri sonucuna ulaşmıştır. $\mathrm{Bu}$ sonuç, mevcut araştırma sonucunda elde edilen bulguyla uyum göstermektedir. Taitz (1996)'da öğretmenlerin sınıf yönetimi yeterliliklerini tespit etmek amacıyla yapmış olduğu araştırmada, öğretmenlerin sınıf yönetimiyle ilgili kendilerini yeterli düzeyde düşündükleri sonucuna ulaşmıştır. Bu sonuç, mevcut araştırma sonucunda elde edilen bulguyla uyumludur. Baloğlu (1998)'de Türkiye'de ilköğretim 1. kademesinde görevli öğretmenlerin sınıf yönetimi becerilerini ölçmek amaciyla yapmış olduğu araştırmada, öğretmenlerin "orta düzeyde" sınıf yönetimi yeterliliğine sahip oldukları sonucuna ulaşmıştır. Baloğlu tarafından ulaşılan bu sonuç, mevcut araştırma sonucunda elde edilen bulguyla örtüşmektedir. Karakoç (1998)'de öğretmenlerin sınıf yönetimi yeterliliklerini belirlemek amacıyla yapmış olduğu araştırmada, öğretmenlerin sınıf yönetimiyle ilgili olarak bu alanda yaşanan gelişmeleri de dikkate kendilerini geliştirmeye çalıştıklarını ve bu doğrultuda çaba sarf ettikleri sonucuna ulaşmıștır. Bu sonuç, mevcut araştırma bulgularını desteklemektedir. Oral \& Şentürk (1998)'de, müfettiş ve öğretmenlerin görüşleri doğrultusunda farklı branşlardan mezun olup sınıf öğretmeni olarak atanan öğretmenlerin mesleki yeterliklerini çeşitli boyutlarda ele alan bir araştırma yapmıştır. Araştırmada; farklı branşlardan mezun olup sınıf öğretmeni olarak çalışan öğretmenlerin kendilerini sınıf yönetimiyle ilgili olarak öğrenme-öğretme sürecini planlama, konu alanı ve ölçmedeğerlendirme boyutlarında "orta" düzeyde yeterli gördükleri sonucuna ulaşılmıştır. Diğer bir taraftan; sınıf içi iletişim, öğretim süreci ve genel mesleki yeterlikler boyutlarında ise öğretmenlerin kendilerini "yüksek" düzeyde yeterli gördükleri sonucuna ulaşılmıştır. Genel olarak ele alındığında bu sonuçlar, sosyal bilgiler öğretmenlerinin sınıf yönetimine ilişkin yeterliliklerini belirlemek amacıyla mevcut araştırmaya katılım gösteren okul yöneticilerinin görüşleriyle uyuşmaktadır. Ağaoğlu (2004)'te öğretmenlerin sınıf yönetimi becerilerinin hangi düzeyde olduğunu tespit etmek amacıyla bir araştırma yapmıştır. Araştırmada, öğretmenlerin sınıf yönetimi becerilerine ilişkin olarak olumlu düşüncelere sahip oldukları sonucuna ulaşmıştır. Genel olarak ele alındığında öğretmenlerin sınıf yönetimi yeterliliklerini artırmaya yönelik eğitim kurumlarının yaptığı çalışmaların olumlu sonuçlar verdiği söylenebilir.

(ii) Yaş değişkenine göre, sosyal bilgiler öğretmenlerinin sınıf yönetimi yeterliliklerine ilişkin okul yöneticilerinin görüşlerinin anlamlı bir farklılık göstermediği sonucuna ulaşılmıştır. Rahimi \& Asadollahia (2012)'de öğretmenlerin sınıf yönetimi yönelimlerini belirlemek amacıyla bir araştırma yapmıştır. Araştırmada, yaş değişkeninin öğretmenlerin sınıf yönetimi yönelimleri üzerinde etkili olmadığı sonucuna ulaşılmıştır. Bu sonuç, mevcut araştırma sonucunda elde edilen bulguyla uyumludur.

Yaş değişkenine göre, sosyal bilgiler öğretmenlerinin sınıf yönetimi yeterliliklerine ilişkin okul yöneticilerinin görüşlerinin puan değerleri arasında, 51 ve üzeri yaş grubunda olan okul yöneticilerinin görüşlerinin en yüksek $(\bar{X}=219.87) ; 41-50$ yaş grubunda olan okul yöneticilerinin görüşlerinin ise en düşük $(\bar{X}=196.50)$ puan değerini oluşturduğu görülmektedir. Yaş grupları arasında değerlendirmeye ilişkin puanlar incelendiğinde; 51 ve üzeri yaş grubunu temsil eden okul yöneticilerinin, sosyal bilgiler öğretmenlerinin sınıf yönetimi yeterliliklerine ilişkin görüşleri diğer yaş gruplarındaki okul yöneticilerine göre daha olumludur.

(iii) Mesleki kıdem değişkenine göre, sosyal bilgiler ögretmenlerinin sınıf yönetimi yeterliliklerine ilişkin okul yöneticilerinin görüşlerinin anlamlı bir farklılık göstermediği, mesleki kıdem değişkeninin okul yöneticilerinin görüşleri üzerinde etkisinin olmadığı sonucuna ulaşılmıştır. Kumarakulasingam (2002)'de öğretmenlerin sınıf yönetimine ilişkin yeterliliklerini belirlemek amacıyla yapmış olduğu araştırmada, mesleki kıdem değişkeninin öğretmen yeterliliği üzerinde önemli bir etken olmadığı sonucuna ulaşmıştır. Bu sonuç, araştırma sonucunda elde edilen bulguyla uyum göstermektedir. Ritter \& Hancock (2007)'de ilkokul öğretmenlerinin sınıf yönetimi yeterliliklerini çeşitli boyutlarda ele alan bir araştırma yapmıştır. Araştırmada, mesleki kıdem değişkeninin ilkokul öğretmenlerinin sınıf yönetimi yeterliliği üzerinde etkili bir unsur olmadığı sonucuna varılmıştır. Ritter \& Hancock tarafindan ulaşılan bu sonuç, mevcut araştırma sonucunda elde edilen bulguyla örtüşmektedir.

Mesleki kıdem değişkenine göre, sosyal bilgiler öğretmenlerinin sınıf yönetimi yeterliliklerine ilişkin okul yöneticilerinin görüşlerinin puan değerleri arasında, 21 ve üzeri yıl mesleki kıdeme sahip olan okul yöneticilerinin görüşlerinin en yüksek $(\bar{X}=217.00) ; 16-20$ yıl mesleki k1deme sahip okul yöneticilerinin görüşlerinin ise en düşük $(\bar{X}=196.66)$ puan değerini oluşturduğu görülmektedir. Sosyal bilgiler öğretmenlerinin sınıf yönetimi yeterliliklerine ilişkin okul yöneticilerinin görüşlerinin puanları, elde edilen değerler çerçevesinde incelendiğinde, mesleki kıdemi 21 ve üzeri olan okul yöneticilerinin görüşlerinin puan değerleri diğer kıdemlerde bulunanlara göre daha olumlu olduğu sonucuna ulaşılmıştır. Aynı zamanda elde edilen değerler genel olarak incelendiğinde, 
mesleki kıdem grupları arasında düzenli bir puan akışının olmadığı gözükmektedir.

(iv) Araştırma sonucunda, okul yöneticilerinin sosyal bilgiler öğretmenlerinin sınıf yönetimi yeterliliklerine ilişkin alan hâkimiyeti boyutunda $(\bar{X}=3.45)$; amaçlı davranış gösterme boyutunda ( $\bar{X}=3.23)$; sınıf içi liderlik boyutunda $(\overline{\mathrm{X}}=3.27)$; planlama boyutunda $(\bar{X}=3.15)$; sınıfta iletişism boyutunda $(\bar{X}=3.28)$; sınıfta davranış yönetimi boyutunda $(\bar{X}=3.26)$; etkinlik yönetimi boyutunda $(\bar{X}=3.02)$; zaman yönetimi boyutunda $(\bar{X}=3.27) ; \quad$ değerlendirme boyutunda $(\bar{X}=3.28)$ puan değerlerine ulaşılmıştır. Okul yöneticileri, sosyal bilgiler öğretmenlerini sinıf yönetiminin alan hâkimiyeti, sınıfta iletişim, değerlendirme, sınıf içi liderlik, sınıfta davranış yönetimi ve zaman yönetimi boyutlarında "yüksek düzeyde yeterli" seviyesinde değerlendirirken; amaçlı davranış gösterme, etkinlik yönetimi ve planlama boyutlarında ise "yeterli" seviyesinde değerlendirmektedir. Ahmad vd. (2012)'de ortaokul öğretmenlerinin sınıf yönetimine ilişkin algılarını belirlemek üzere bir araştırma yapmıştır. Araştırmada, ortaokul öğretmenlerinin sınıf yönetiminin planlama ve etkinlik yönetimi alt boyutlarında düşük düzeyde yeterli olduğu sonucuna ulaşılmıştır. Bu sonuç, mevcut araştırma sonucunda elde edilen bulgularla örtüşmektedir. Genel olarak değerlendirildiğinde okul yöneticilerinin, sosyal bilgiler öğretmenlerinin sınıf yönetimi yeterliliklerine ilişskin düşünceleri olumludur. Sınıf yönetimi alanında yapılan çalışmaların olumlu sonuç verdiği söylenilebilir.

Mevcut konu alanıyla ilgili olarak araştırmaların çeşitlendirilmesi ve farklı boyutlarıyla ele alınıp değerlendirilebilmesi için şu önerilerde bulunulabilir:

(i) $\mathrm{Bu}$ alanla ilgili daha kapsamlı veriler elde etmek için araştırmalarda öğretmen, öğrenci ve denetçilerin de görüşleri alınarak araştırmanın boyutları genişletilebilir.

(ii) Sosyal bilgiler öğretmenlerinin "etkinlik yönetimi" boyutunda kendilerini geliştirmelerine olanak sağlayacak çalışmalar yapılması önerilmektedir.

(iii) Sosyal bilgiler öğretmenlerinin sınıf yönetimi boyutlarındaki yeterliliklerinin belirlenmesinde daha kapsamlı nicel ve nitel araştırmalar yapılabilir.

(iv) Sosyal bilgiler öğretmenlerinin sınıf yönetimine ilişskin yeterlilikleri ile sınıf yönetimi tarzları arasındaki ilişkiyi ele alan araştırmalar yapılabilir.

(v) Hem sosyal bilgiler öğretmenlerinin hem de okul yöneticilerinin sınıf yönetimiyle ilgili bilgilerini ve duyarlılıklarını artırmaları için bu alanda yaşanan gelişmeleri takip etmeleri önerilmektedir.

\section{Kaynakça}

Ağaoğlu, E. (2003). Sınıf yönetimi. İçinde: Z. Kaya (Ed.), Sinıf yönetimi ile ilgili genel olgular (ss. 1-42). Ankara: Pegem Yayıncilık.
Ağaoğlu, E. (2004). The opinions of teacher candidates about their own skills of classroom management. Paper presented at the 29th Annual Conference of Association for Teacher Education in Europe, 23-27 October 2004.

Ahmad, I., Rauf, M., Zeb, A., Rehman, S., Khan, W., Rashid, A., \& Ali, F. (2012). Teachers' perceptions of classroom management, problems and its solutions: Case of government secondary schools in Chitral, Khyber Pakhtunkhwa, Pakistan. International Journal of Business and Social Science, 3(24), 173-181.

Arslan, H. (2008). Sınıf yönetimi. İçinde: M. Şişman-S. Turan (Ed.), Sinıf kurallarının oluşturulması (ss. 97111). Ankara: Pegem Akademi Yayınları.

Aydın, A. (2012). Sinıf yönetimi.. Ankara: Pegem Akademi Yayınları.

Baloğlu, N. (1998). Sinıf ögretmenlerinin sinıf yönetimi yeterlikleri hakkında ilkögrretim müfettişlerinin görüşleri. Yüksek Lisans Tezi. Ankara: Gazi Üniversitesi.

Başar, H. (2005). Sinıf yönetimi.. Ankara: Anı Yayıncılık.

Burden, P. R. (2003). Classroom management: Creating a successful k-12 learning community. Hoboken, NJ: John Wiley \& Sons, Inc.

Çalık, T. (2009). Sınıf yönetimi. İçinde: L. Küçükahmet (Ed.), Sinff yönetimi ile ilgili temel kavramlar (ss.1-16). Ankara: Pegem Akademi.

Darling-Hammond, L. (2006). Powerful teacher education: Lessons from exemplary programs. San Francisco: John Wiley and Sons Inc.

Demir, C. (2006). Fizik ögretmenlerinin slnıf yönetimine ilişkin algllarl ve tutumları üzerine bir araştırma. Yüksek Lisans Tezi. Diyarbakır: Dicle Üniversitesi.

Demirtaş, H. (2005). Etkili sınıf yönetimi. İçinde: H. Kıran (Ed.), Sinıf yönetiminin temelleri (ss. 1-33). Ankara: Anı Yayıncilık.

Farooq, M. S. (2011). Perceptions of prospective teachers about factors influencing classroom management. Journal of Quality and Technology Management, 7(1), 23-38.

İpek, C. (2003). Sınıf yönetimi. İçinde: Ö. Üre (Ed.), Sinıf ortamında ögretmen (ss. 91-126). Ankara: Mikro Yayınları.

Johnson, D., Turgut, F., Ayas, A., \& Çepni, S. (1997). Fizik öğretimi. Ankara: Yükseköğretim Kurulu Yayınları.

Karakoç, H. S. (1998). Çanakkale ili ilköğretim kurumları ögretmenlerinin sinlf yönetimindeki yeterlilikleri. Yüksek Lisans Tezi. Çanakkale: Çanakkale Onsekiz Mart Üniversitesi.

Karasar, N. (2012). Bilimsel araştırma yöntemi. Ankara: 3A Araştırma Eğitim Danışmanlık Ltd. Şti.

Koçak, R., \& Akın, U. (2007). Öğretmenlerin sınıf yönetimi becerileri ile iş doyumları arasındaki ilişki. Kuram ve Uygulamada Ĕ̈itim Yönetimi Dergisi, 51, 353-370.

Kumarakulusingam, T. M. (2002). Relationships between classroom management, teacher stress, teacher burnout 
and teachers levels of hope. $\mathrm{PhD}$ Thesis. Manhattan: University of Kansas.

Kuran, K. (2002). Öğretmenlik mesleğine giriş. İçinde: A. Türkoğlu (Ed.), Öğretmenlik meslĕ̆i (niteliği ve önemi) (ss. 253-278). Ankara: Mikro Yayınları.

Oral, B. (2000). Öğretmen adaylarının ortaöğretimde çalışan öğretmenlerin öğretim davranışlarına ilişkin algıları. Ĕgitim ve Bilim Dergisi, 25(115), 28-34.

Oral, B., \& H. Şentürk, H. (1998). Farklı branşlardan mezun olup sınıf öğretmeni olarak atanan öğretmenlerin mesleki yeterliklerine ilişkin müfettiş ve öğretmenlerin algıları. Ĕgitimde Yansimalar: IV Cumhuriyetin 75. Yllında Ilköğretim I. Ulusal Sempozyumu, 27-28 Kasım, Ankara.

Özer, F. (2013). Aday öğretmenlerin sınıf yönetimine ilişkin algıları. Yüksek Lisans Tezi. Elazığ: Fırat Üniversitesi.

Rahimi, M., \& Asadollahia, F. (2012). EFL teachers' classroom management orientations: Investigating the role of individual differences and contextual variables. Procedia-Social and Behavioral Sciences, 31, 43-48.

Ritter, J. T., \& Hancock, D. R. (2007). Exploring the relationship between certification sources, experience levels, and classroom management orientations of classroom teachers. Teaching and Teacher Education: An International Journal of Research and Studies, 23(7), 1206- 1216.

Rosas, C., \& West, M. (2009). Teachers' beliefs about classroom management: Pre-service and inservice teachers' beliefs about classroom management. International Journal of Applied Educational Studies, 5(1), 54-61.

Sarıtaş, M. (2006). Öğretmen adaylarının değerlendirmelerine göre sinıfta istenmeyen öğrenci davranışlarını değiştirmek ve düzenlemek amacıyla yaralanılan stratejiler. Eğitim Fakültesi Dergisi, 19(1), 67-187.

Sharma, S. L. (2009). Educational management: A unified approach of education. New Delhi: Global India Publications Pvt. Ltd.

Simonsen, B., Fairbanks, S., Briesch, A., Myers, D., \& Sugai, G. (2008). Evidence-based practices in classroom management: Considerations for research to practice. Education and Treatment of Children Journal, 31(3), 351-380.

Taitz, M. (1996). Discipline, democracy and developmentally appropriate curriculum: or what constitutes effective classroom management in the early primary grades. Educational Resources Information Center (ERIC), 143, 1-18.

Yalçınkaya, M. (2003). Sınıf yönetimi. İçinde: Ö. Üre (Ed.), Sınıf-içi istenmeyen ögrenci davranışlart ve yönetimine ilişkin stratejiler (ss. 183-212). Ankara: Mikro Yayınları. 